\title{
Study on Patent Strategy of Emerging industry in China
}

\author{
Bao Meng-meng* 1,a, Wu Jian-long 2,b \\ ${ }^{1}$ School of economics and management, Harbin University of Science and Technology, Harbin 150080, China \\ ${ }^{2}$ School of economics and management, Harbin University of Science and Technology, Harbin 150080, China
}

\begin{abstract}
Patent strategy has become an important strategic means to elevate independent innovation capability and international competitiveness of emerging industry. Thus, based on connotation analysis of patent strategy of emerging industry, the paper designs influencing factors analysis framework for industry patent strategy, and puts forward industry patent strategy position, and then builds promoting process of industry patent strategy around patent development, application, use and protection, so as to provide theory and method support for patent strategy management of emerging industry.
\end{abstract}

\section{INTRODUCTION}

In the era of digital economy, the creating and using of the intellectual property rights is the main indicator of independent innovation, patent strategy is bound to become an important means of engaging in the global competition of emerging industry. However, the integral of emerging industry in China lacks of patent awareness and patent strategy and core technology, and meanwhile being incurred patent siege by the developed countries and the Multi-National Corporation at present. This series of "internal disturbance foreign aggression" problem has restricted the development of rapid and sustained of emerging industry in China.

Thus, how to construct the patent strategy of the emerging industry have become the outstanding problems faced by emerging industry. However, there is few research involving the patent strategy of the emerging industry at present, more scholars have explored patent strategy in enterprise level, for example, the impact of patent strategy on the value of domestic enterprises or international entrepreneurship [1][2]. Therefore, there is the important theory value and practical significance on system study of the patent strategy of emerging industry.

\section{CONNOTATION AND FACTORS OF THE PATENT STRATEGY OF EMERGING INDUSTRY}

\section{A. Definition of the Patent Strategy of Emerging Industry}

Patent strategy serve for the need of independent innovation and sustainable development in the emerging industry, and it is the important guarantee of sustainable competitive advantages of industry development. Therefore, the patent strategy of emerging industry is defined as: long-term and master plan of the development of the industry patent strategy; based on the independent innovation; according to the needs of internal and external environment, industry's advantages and overall development; taking overall positioning of the development of patent of industry; and take the strategy of the development, application, use and protection of patent further.

The patent strategy of emerging industry also has a certain hierarchy, and it can be divided into the overall strategy and specific strategies. Among them, the overall patent strategy refers to gear to the needs of the overall development of cluster and the independent innovation strategy and strategy position of the development trend of patent of emerging industry; and the specific patent strategy is a series of sub-strategies around key links of the independent innovation of emerging industry, and it is a specific and implementation process of the overall patent strategy of the industry.

\section{B. Features of Patent Strategy of Emerging Industry}

Patent strategy of emerging industry has its particularity: (1) comprehensive, the patent strategy synthetically reflects innovation organization, patent technology, the diversity of the competitive environment and complex association of the emerging industry; (2) mass, the patent strategy of the emerging industry is the mass representation of patent activities and interaction of many emerging technology enterprises and related institutions; (3) from property, patent strategy belongs to independent innovation and sustainable development strategy of emerging industry; (4) globalization, internationalization degree of patent strategy of emerging industry is higher than that of traditional industry.

\footnotetext{
a*baomm@stu.hrbust.edu.cn bwuj11981@sohu.com
} 


\section{Factors of Patent Strategy of Emerging Industry}

Clarifying key influence factors is the premise of scientific formulation of the patent strategy of emerging industry, we carry on the analysis to factors of patent strategy of emerging industry with analyzing dimensions using GEM model proposed by Tim and Hervey (1998) [3][4] and combining characteristics of patent strategy, as shown in table I.

TABLE I.

FACTORS OF THE PATENT STRATEGY OF EMERGING INDUSTRY

\begin{tabular}{|c|c|l|}
\hline Model & Name & \multicolumn{1}{c|}{ Composition factors } \\
\hline \multirow{3}{*}{$\begin{array}{c}\text { Factors I } \\
\text { Basics }\end{array}$} & Resources & $\begin{array}{l}\text { Patent technologies reserve, patent creation and management personnel, scientific research resources, } \\
\text { et al. }\end{array}$ \\
\cline { 2 - 4 } & Facilities & $\begin{array}{l}\text { (1)Hardware facilities: the level of development of R\&D services of patent technologies (such as } \\
\text { informational indexing mechanism), apply for agent service (such as agencies), industrial service (such } \\
\text { as incubation base) and management services (such as industry associations, management consulting } \\
\text { agencies), et al; (2) software facilities: policies of innovation incentive, innovation cultural, patent } \\
\text { technologies market, the situation of laws and regulations of the patent and implementation. }\end{array}$ \\
\hline \multirow{3}{*}{$\begin{array}{c}\text { Factors II } \\
\text { Enterprises }\end{array}$} & $\begin{array}{c}\text { Suppliers and } \\
\text { related enterprises }\end{array}$ & $\begin{array}{l}\text { Structures, } \\
\text { and local suppliers; (2) inter-organizational innovation degree of relevancy of the emerging industry, } \\
\text { such as cooperative; (3) technical consensus and matching between dominant enterprises and related } \\
\text { enterprises. }\end{array}$ \\
\cline { 2 - 4 } & $\begin{array}{l}\text { strategies and } \\
\text { competitions of } \\
\text { enterprises }\end{array}$ & $\begin{array}{l}\text { industry innovation strategy planning and consistency; (3) the patent innovations in the industry orderly } \\
\text { competition and external competitive level. }\end{array}$ \\
\hline \multirow{2}{*}{$\begin{array}{c}\text { Factors III } \\
\text { Market }\end{array}$} & Local market & $\begin{array}{l}\text { The number of emerging industry products and local market share respond to the needs of the local } \\
\text { market product innovation efficiency. }\end{array}$ \\
\cline { 2 - 4 } & External market & $\begin{array}{l}\text { Emerging products of the region and even the global market share, blending into the global value chain } \\
\text { and innovation chain disorder. }\end{array}$ \\
\hline
\end{tabular}

\section{STRATEGIC POSITIONING OF EMERGING INDUSTRY}

Its own strength and influence of the critical factors of the industry determine its patent strategic positioning; overall, the strategic positioning of patent of emerging industry can be divided into two categories of offensive and defensive. Offensive patent strategy primarily serves the development needs of expansion of emerging industry, while the defensive patent strategy is to maintain the competitiveness of emerging industry or avoid being eroded, applicable conditions is shown in table II.

\section{PROMOTE PROCESS OF PATENT STRATEGY OF EMERGING INDUSTRY}

According to the process of independent innovation of emerging industry, on the basis of patent strategic positioning, they promote strategy according to the four stages of emerging industry patent development, patent applications, patent application and patent protection.

\section{A. Patent Development Strategy}

Patent development is the starting point of promoting patent strategy of emerging industry, and they need to layout to match the subject and object of patent strategy according to the need of innovation capability and development requirements of industry, that is the strategic purpose of industry patent development must be clear and the most effective and feasible of the develop of organization need to be considered, as is shown in table III.

\begin{tabular}{|c|c|}
\hline $\begin{array}{c}\text { Type of } \\
\text { position } \\
\text { patent } \\
\text { strategies }\end{array}$ & \multicolumn{1}{c|}{ Applicable Conditions } \\
\hline $\begin{array}{c}\text { Offensive } \\
\text { patent } \\
\text { strategies }\end{array}$ & $\begin{array}{l}\text { They are suitable for industry of owning rich innovational } \\
\text { resources and replete hardware \& software equipment, } \\
\text { enterprises has a high degree of association of technology } \\
\text { and distinguished advantages of innovation, and they } \\
\text { possess absolute advantages in the local market and } \\
\text { external markets of great potential for development. }\end{array}$ \\
\hline $\begin{array}{c}\text { Defensive } \\
\text { patent } \\
\text { strategies }\end{array}$ & $\begin{array}{l}\text { They are suitable for industry of lacking innovation } \\
\text { resources or unsound related implementation, cooperative } \\
\text { innovation of enterprises is not high or competition is } \\
\text { disorder, the local market has external threats or high } \\
\text { barriers involved in the external market. }\end{array}$ \\
\hline
\end{tabular}


TABLE III. PATENT DEVELOPMENT STRATEGY OF EMERGING INDUSTRY

\begin{tabular}{|c|c|}
\hline The key of patent development & Subject of patent development \\
\hline $\begin{array}{c}\text { Development strategy of the key common technology, breakthroughs in } \\
\text { bottlenecks of key common technology of the whole development of the } \\
\text { cluster, to enhance the whole of level of technology of the emerging } \\
\text { industry. }\end{array}$ & $\begin{array}{c}\text { Because of such technology has a strong externalities, } \\
\text { government's participation or leading is the inevitable, universities } \\
\text { around the cluster core, research institutions and high-end Industry- } \\
\text { University-Research Alliance is formed by enterprise conduct } \\
\text { joint research often become the main development. }\end{array}$ \\
\hline $\begin{array}{c}\text { Development Strategy of Core Technology. Master patented technology of } \\
\text { core product or service, establishing the Technology with Special } \\
\text { Advantages from emerging industry involved in wider range of competing. }\end{array}$ & $\begin{array}{c}\text { Core business of emerging industry and the leading R\&D alliances } \\
\text { becomes the subject of such patent development. }\end{array}$ \\
\hline $\begin{array}{c}\text { Development strategy of general common technology. To strengthen the } \\
\text { competition before technology series development, make up for the } \\
\text { weaknesses in the innovation chain of patented technology. }\end{array}$ & $\begin{array}{c}\text { Under the subsidization and encourages of government, the } \\
\text { university and foundational scientific research institution are the } \\
\text { subject of main innovation. }\end{array}$ \\
\hline $\begin{array}{c}\text { Development strategy of matching technology. Enhancing industrial } \\
\text { innovation, and forming a network of patent to protect key common or core } \\
\text { technologies of emerging industry. }\end{array}$ & $\begin{array}{c}\text { Many small and medium high-tech enterprises within the industry } \\
\text { to become the subject of such patent technology development. }\end{array}$ \\
\hline
\end{tabular}

\section{B. Patent Application Strategy}

The patent application is a comprehensive layout of patent technology dimension, market and legal dimension, industry strategic of patent application focus on whether to apply for various types of technology, the application

TABLE IV. STRATEGIC DECISIONS OF PATENT APPLICATIONS

\begin{tabular}{|c|c|c|c|}
\hline $\begin{array}{l}\text { Patent } \\
\text { technology } \\
\text { type }\end{array}$ & $\begin{array}{l}\text { Whether to } \\
\text { apply }\end{array}$ & Scope of application & Distribution of the patent right \\
\hline \multirow[t]{2}{*}{$\begin{array}{l}\text { The key } \\
\text { common } \\
\text { technology }\end{array}$} & $\begin{array}{l}\text { Apply for a } \\
\text { patent }\end{array}$ & $\begin{array}{l}\text { Apply for patent in this region } \\
\text { where may be the presence of } \\
\text { competitors }\end{array}$ & $\begin{array}{l}\text { If science \& technology program support the patent of development, } \\
\text { the government retains patent ownership; if the college or alliances } \\
\text { collaborative development, then follow the "who will develop, who } \\
\text { will owns" or cooperative agreement. }\end{array}$ \\
\hline & Internal public & 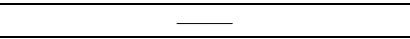 & - \\
\hline \multirow{2}{*}{$\begin{array}{l}\text { General } \\
\text { common } \\
\text { technology }\end{array}$} & Application & Usually apply for a patent in China & Follow the "who will develop, who will owns". \\
\hline & Internal public & & \\
\hline \multirow{2}{*}{$\begin{array}{l}\text { Core } \\
\text { Technology }\end{array}$} & $\begin{array}{l}\text { Applications for } \\
\text { patents }\end{array}$ & $\begin{array}{l}\text { Maximum scope for competition } \\
\text { applied for patents }\end{array}$ & $\begin{array}{c}\text { Follow the "who will developed, who will owns" partnership or } \\
\text { cooperation agreement of alliances. }\end{array}$ \\
\hline & $\begin{array}{l}\text { Technical } \\
\text { Secrets }\end{array}$ & 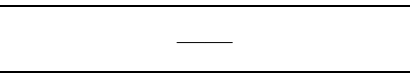 & 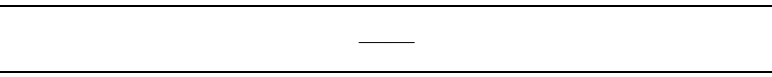 \\
\hline \multirow{2}{*}{$\begin{array}{l}\text { Matching } \\
\text { technology }\end{array}$} & Application & Usually apply for a patent in China & Follow the "who will developed, who will owns". \\
\hline & Do not apply & - & - \\
\hline
\end{tabular}

\section{Patent Use Strategy}

The achievement transformation of emerging industry is the basis of maximization of utility patents. According to the patent technical characteristics and the level of competition, patent use strategy of emerging industry can be divided into patent shares, transfer of patent rights, patent cross-licensing, entrepreneurship based on patent technology, building patent pool and standardization of the patent technology and other specific forms.

- Patent shares. In addition to some internal disclosure commonalities technology can be shared within emerging industry, the ownership of the government's patent technology can also be shared within the emerging industry. In addition, government can allow common patented technology of some universities and research institutions be shared within emerging industry through subsidy and other motivational patterns.

- The transfer of patent rights. Emerging technology within the emerging industry has well application scope, and ownership allocation for strategic decisionmaking, thereby improving the efficiency of patent application. Combined with strategic positioning of emerging industry and a variety of technical features, the specific application strategic decisions are shown in table IV. 
emerging industry, to build patent pools by core businesses, universities and research institutions [5], to become important means of emerging industry who involved in broader competition.

- Standardization of the patent technology. Current emerging industry competition has been upgraded to core technology competition, around a series of key technologies of specific areas and core technology patents operational technical standards, it is necessary for a certain strength of emerging industry.

\section{Patent Protection Strategy}

Patent protection throughout all aspects of innovation, it is a concentrated expression of effective use of the patent system. Getting together to form the technology spillover among emerging technology enterprises, accelerating the innovation process, it also can cause a lot of enterprises "hitchhike" phenomenon, contusing enthusiasm of enterprise innovation. Therefore, emerging industry patent protection of the emerging technology enterprise has its particularity, not only to comply with international patent law and domestic patent law, but the need to build the optimal patent protection system within emerging industry, which formed a three-tier system of patent protection , as shown in Figure 1.

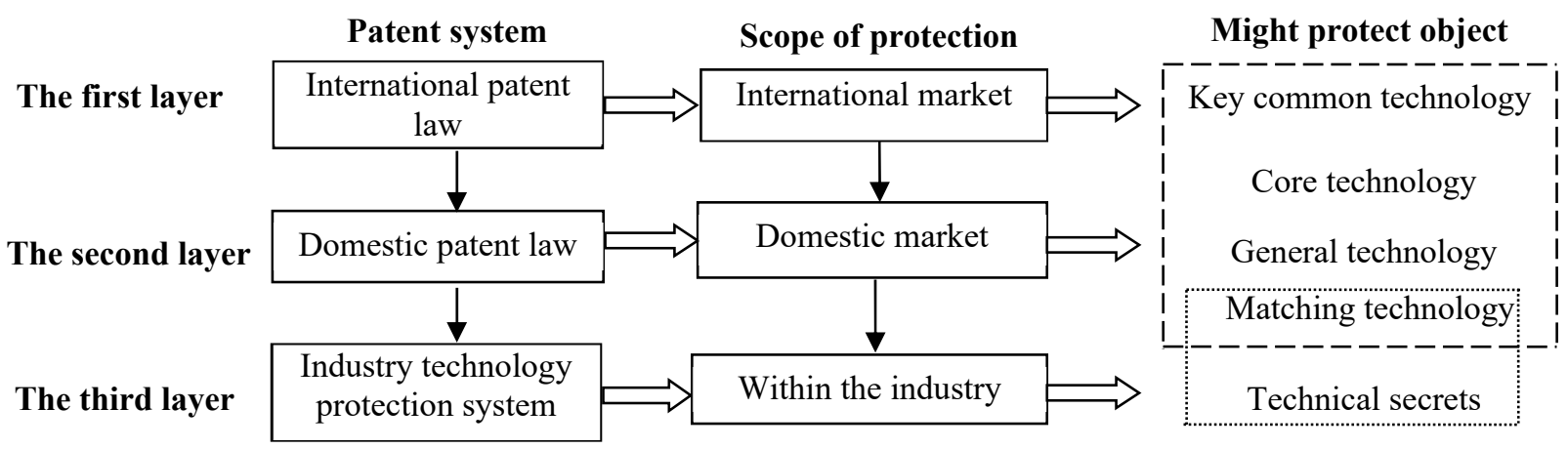

Figure 1. Three-level of patent protection of emerging industry

International and domestic patent laws apply strict legal regulations to protect patents, and it is first and second floor of patent protection about emerging industry. Lack of protection and protection too much for technology within the industry will affect the overall innovation effect of the industry, therefore, we need to develop appropriate technical protection system within the industry, focus on the protection of technology secret of enterprise and part of the matching technology, among them, technical secrets include core technology which is not suitable for application patent, and there is a lot of technology which didn't meet the requirements of national patent or update speed is quite quick. Therefore, through trade associations, industry management, and core enterprise technology led the development about protection systems of industry technological enrollment, the specific scope of protection may refer to the national patent claims, and reducing height, width and length of the patent protection adequately. Once the violations occurred among emerging industry enterprises, the industry internal regulatory agencies and industry associations should crack down, thus create a favorable environment within the industry patent protection. In short, the international patent law is more inclined to attack the escort for the patent of emerging industry, and the protection system within the industry is in order to better regulate innovation order of the industry.

\section{CONCLUSIONS}

Emerging industry is important part which can improve our capability of independent innovation and international competitiveness, what's more, promoting important channel of patent strategy. According to emerging industry innovation strength, diversity of competitive potential and difference of key influence factors, its patent strategy is divided into offensive and defensive patent strategies; on the basis of positioning of patent strategy for emerging industry, promoting the specific process of patent strategy to followed by patents development strategy, strategy of patent application, strategy of patent use and strategy of patent protection, and the four aspects are coordinated and interlocking, and it is the specific positioning and implementation process for patent strategy of emerging industry. This research can provide theoretical guidance and decision-making reference for development and implementation of patent strategy of emerging industry.

\section{ACKNOWLEDGMENT}

This research was supported by the National Natural Science Foundation (71503061, 72074061), the Heilongjiang Philosophy and Social Sciences Foundation (19JYB024), Heilongjiang Natural Science Foundation (LH2020G007).

\section{REFERENCES}

1. Jia Ruiqian, Chen Song, Li Lian, "Impact of patent portfolio on corporate value of Shanghai listed manufacturing companies", Science Research Management, vol. 40, pp. 198-205, August 2019.

2. Zeng Yu, Peng Huatao, "The The Influence Mechanism of Patent Strategy on International Entrepreneurship:A Two-Case Study 
Based on Haier and Huawei". Forum on Science and Technology in China, vol. 5, pp. 68-76, May 2019.

3. Kogan L, Papanikolaou D, Seru A, Stoffman N. "Technological Innovation, Resource Allocation, and Growth", The Quarterly Journal of Economics, vol. 132, pp. 665-712, February 2017.

4. Tim Padmore, Hervey Gibson. "Modeling systems of the innovation: a framework for industrial cluster analysis in region", Research Policy, vol. 26, pp. 625-641, June 2010.
5. Michael R, Franzinger. "Latent dangers in a patent pool: the European commission's approval of the $3 \mathrm{G}$ wireless technology licensing agreements", California Law Review, vol. 91, pp. 1695-1728, June 2003 